\title{
THOMAS HODGKIN AND BENJAMIN HARRISON: CRISIS AND PROMOTION IN ACADEMIA
}

\author{
by
}

\author{
EDWARD H. KASS, ANNE B. CAREY, AND AMALIE M. KASS*
}

On the night of 15 June 1837 Dr. James Cholmeley, Physician to Guy's Hospital, died. The ultimate consequences of this event were only slightly less far-reaching for Dr. Thomas Hodgkin than for his late colleague. Dr. Cholmeley's death created an opening at Guy's Hospital to which Dr. Thomas Addison was almost certain to be appointed. The vacancy created by Addison's advancement was for an appointment as Assistant Physician that was coveted by Thomas Hodgkin, but he was destined not to receive it. Given his medical eminence, it has never been entirely clear why Hodgkin was rejected. Correspondence has been made available to us that provides some understanding of what occurred.

Few eponyms in medicine have been as durable as the one which bears the name of Thomas Hodgkin. The eponym, coined initially by Samuel Wilks, was attached to the unusual gross appearance of lymph nodes in certain fatal disorders, and it is a tribute to Hodgkin's perception that later microscopic study of the original case material showed that many of the cases were indeed those of an unusual lymphoid disorder whose nature and etiology are still uncertain. ${ }^{1}$ Wilks, as a pathologist and historian at Guy's Hospital, later recognized similar cases and had the uncommon generosity of spirit to record that there were earlier descriptions by Hodgkin of what appeared to be the same disease. Wilks, with Bettany, wrote a history of Guy's Hospital ${ }^{2}$ and provided many details about Hodgkin.

Wilks' biographical sketch indicated that despite Hodgkin's evident accomplishments he was not promoted to Assistant Physician following the death of Dr. Cholmeley and that shortly thereafter he moved to St. Thomas' Hospital where he was active in delivering medical care to the underprivileged and continued to publish from his vast store of medical experience. However, much of the remaining thirty years of his life was devoted to social reform, geographical explorations (he was for many years secretary to the Royal Geographical Society), ethnology, and the problem of slavery and the colonization of freed slaves in Africa; he played an important role in the fates of Sierra Leone and Liberia. He was a member of the first Senate of the University of London, which was the first university in England that granted degrees to

\footnotetext{
*Edward H. Kass, M.D., Ph.D., Anne B. Carey, B.A., and Amalie M. Kass, B.A., M.Ed. From the Channing Laboratory, Department of Medicine, Harvard Medical School, and Peter Bent Brigham Hospital Division of the Affiliated Hospitals Center, Inc., Boston, Massachusetts. Aided by a grant from the Commonwealth Fund.

${ }^{1}$ Herbert Fox, 'Remarks on the presentation of microscopical preparations made from some of the original tissue described by Thomas Hodgkin, 1832', Ann. med. Hist., 1926, 8: 370-374.

2 Samuel Wilks and G. T. Bettany, Biographical history of Guy's Hospital, London, Ward, Lock, Bowden, 1892 , pp. $380-386$.
} 


\section{Edward H. Kass, Anne B. Carey, and Amalie M. Kass}

Dissenters. His many other interests and achievements are astonishing in their scope and social value. ${ }^{3}$

Many of Hodgkin's non-medical interests were already evident even while he was engaged in his early medical activities: he established the first pathological museum at Guy's (it is still one of the finest in the world); he gave some of the first systematic lectures in pathology in England; he introduced the stethoscope to Great Britain and described a variety of medical disorders. He also pioneered in the use of the achromatic microscope. Meanwhile he was goading his colleagues on the faculty toward reform of the medical curriculum, and working toward a more equitable system of distribution of health maintenance and health delivery services for the poor. ${ }^{4}$

Nevertheless, he did not receive the promotion that he wanted, and Wilks, in his brief notation, indicates, a bit darkly, that there was much left unsaid in the available records of the time.

Turmoil in academia is hardly unique to England of the early nineteenth century. Nevertheless, each event offers an insight into the characters, the culture, and the time, much as a disease gives insight into normal function. Therefore the events surrounding Dr. Hodgkin's proposed promotion have been reconstructed from his correspondence and other writings of the time.

In order to understand the events that surround the rejection of Hodgkin's promotion it is necessary to recount the connexion with the Hudson's Bay Company of Mr. Benjamin Harrison, the all-powerful Treasurer of Guy's Hospital. * Harrison had been associated with the Hudson's Bay Company since 1809, when he became a member of its Committee, the seven-member policymaking body for the company. The powers granted to the Committee by the Royal Charter of 1670 were vast and included the right to make laws, to administer justice, to undertake military expeditions, and to make war or peace with non-Christian peoples, as well as to enjoy a total monopoly of trade in all territory drained by Hudson's Bay and its tributaries, covering most of the eastern two-thirds of what is now Canada. ${ }^{5}$

Harrison was a devout Anglican, part of the Clapham Sect, a group of evangelical reformers who were interested in many humanitarian efforts such as abolition of the slave trade. 6 The Claphamites, or "Saints," have been characterized by historians as

3 E. H. Kass, 'Thomas Hodgkin, physician and social scientist', Guy's Hosp. Rep. , 1966, 115: 269-280; Edward H. Kass and Anne H. Bartlett, 'Thomas Hodgkin, M.D. (1798-1866): an annotated bibliography', Bull. Hist. Med, 1969, 63: 138-175; G. E. H. Foxon, 'Thomas Hodgkin, 1798-1866, a biographical note', Guy's Hosp. Rep., 1966, 115: 243-254.

4 Thomas Hodgkin, Lectures on the means of promoting and preserving health, London, J. G. A. Arch, 1835.

*The Dictionary of national biography (1908) tells of Harrison that “. . . for 50 years he governed the hospital and managed its estates despotically without salary. One of Cruickshank's [sic] caricatures depicts him as a king sitting on a throne with his subjects prostrating themselves abjectly before him."

5 Robert E. Pinkerton, Hudson's Bay Company, New York, Henry Holt, 1931 : Beckles Wilson, The great Company (1667-1871), London, Smith, Elder, 1900, 2 vols.; E. E. Rich, The history of the Hudson's Bay Company 1670-1870, vol. II, 1763-1870, London, Hudson's Bay Record Society, 1959; George Bryce, The remarkable history of the Hudson's Bay Company, including that of the French traders of North-western Canada and of the North-West, XY, and Astor Fur Companies, London, Sampson Low, Marston, 1900.

6 R. de M. Rudolf, 'The Clapham Sect', Clapham and the Clapham Sect, Clapham, Edmund Baldwin for the Clapham Antiquarian Society, 1927. 


\section{Thomas Hodgkin and Benjamin Harrison: crisis and promotion in academia}

possessed with a "vague, universal and self-righteous humanitarianism"7 and as wishing not "to abolish the distinction between high and poor or to shatter the traditionalist theory of orders, ranks and degrees, but rather to justify both by introducing into the world a new leaven of righteousness". 8 This combination of motivations led to a peculiar but wholly logical emphasis on the salvation of souls rather than of bodies and it has been said of some members of the sect that they "were almost inclined to congratulate the poor on their poverty, because it made easier their path to heaven". 9

Thus, in addition to a keen interest in the economic well-being of the Hudson's Bay Company, Harrison was also able to see the Company as a philanthropic endeavour. He had supported the cession of a large tract of company land near the Red River for the settlement of indigent Irish and English peasants (the Selkirk plan) and had maintained his concern for this enterprise over the years. ${ }^{10}$ Justifying a later description as "a noted and active philanthropist" and as one with an "humanitarian spirit",11 he was instrumental in having a chaplain appointed to the colony and corresponded with that chaplain concerning the appointment of a Chief Factor to superintend new settlers and to build a school of industry for orphans. 12

Nevertheless, the primary interest of the Hudson's Bay Company was the fur trade and it seems likely that the company did not put the well-being of the native suppliers at the top of its list of priorities. Furthermore, the evangelicals such as Harrison who were on its Committee were several thousand miles distant from the objects of their decisions and it is probable that actions within the territories exerted greater influence on dealings with the Indians than did the general policies sent from London. In any case, given Harrison's long service and commitment to the Company and his strong and autocratic personality, it is not hard to imagine that he would construe as a personal reflection any criticism of company policies or practices.

In 1833, Dr. Richard King, a colleague of Hodgkin's at Guy's, set out on an expedition to the shores of the Arctic Ocean, under the command of Captain George Back of the Royal Navy. King was surgeon and naturalist for the party, and before his departure, he sought the ideas of his friend Hodgkin for useful observations to be made in the course of the journey. Hodgkin, ${ }^{13}$ with characteristic thoroughness, sent a series of suggestions concerning the temperature of animals living in a cold environment, the effects of meteorological phenomena on members of the expedition and natives, the mortality among the local inhabitants at different times of the year, the flora and fauna, and the geological formations and mineral deposits. However, the state of the

7 G. T. Garratt, Lord Brougham, London, Macmillan, 1935, p. 23.

8 Asa Briggs, The age of improvement, London, Longmans, Green, 1959, p. 71.

9 James A. Williamson, $A$ short history of British expansion, vol. II; The modern empire and Commonwealth, 5th ed., London, Macmillan, 1964, p. 20.

10 See note 5 above.

11 Rich, op. cit., note 5 above, pp. 345, 422.

12 Eugene Stock, The history of the Church Missionary Society; its environment, its men and its work, London, Church Missionary Society, 1899, vol. I, p. 246.

13 Papers of Thomas Hodgkin have been copied on microfilm and are deposited at the Wellcome Institute for the History of Medicine, London, and the Countway Library, Harvard Medical School, Boston. The citations refer to the reel and frame, hence, this reference is to $11: 181$, namely reel no. 11 and frame no. 181 . 


\section{Edward H. Kass, Anne B. Carey, and Amalie M. Kass}

aboriginal tribes was Hodgkin's greatest concern. Hodgkin pointed out, in his letter to King, that these tribes were rapidly disappearing and remaining Indians were often "much debased and degraded". He urged King to collect as much information as he could about the origins, traditions, languages, religions, and ways of life of these tribes. Hodgkin's list of particulars foreshadows a more structured questionnaire which he later formulated for the British Association as an aid to collection and classification of data on the varieties of the human race, ${ }^{14}$ particularly those threatened with extinction. His scientific training was evident in his insistence on large numbers of observations, on accuracy in reporting, on confirming important observations from independent sources, and on the recognition of possible bias in secondary sources of information such as missionaries, traders, or interpreters. There was already realization that the tribes of North America probably entered the continent through the North West territories, and therefore observations on these tribes might have particular value in ethnological studies.

Finally, in the letter to King, Hodgkin revealed his social concerns and patriotic feelings. Observing that uncivilized nations had suffered so many losses at the hands of those who called themselves Christians, Hodgkin suggested that "travellers should now begin a different course and direct their attention to the means by which the natives may be ameliorated whilst the productions of their country are sought for our advantage." He did not wish to interfere with the commercial advantages of trade, but only to make them reciprocal. He hoped King "may have the means of . . . promoting the Education of the Sons of Chiefs in our Canadian Schools and Colleges." Hodgkin pointed out that "The increase in civilization of our Indian allies must not only be conducive to our commercial prosperity but to our territorial security" for the rapid expansion of American and Russian enterprises would be checked by a truly civilizing influence among the nations. Therefore Hodgkin strongly urged that the leader of the expedition should attempt to impress the agents of the Hudson's Bay Company with the advantages to themselves, as well as to the Indians, of a more liberal policy toward the latter.

King's assessment of the situation on his arrival in North America was gloomy indeed and his letter to Hodgkin confirmed the latter's fears. He found the natives to be in a state of decline, suffering the ill effects of rum and venereal disease. He wrote to Hodgkin from Fort Reliance in April 1833 as follows: "As to the amelioration of their condition it is only to be accomplished by the strong arm of Government. I may remark, altho' for the present, out of respect to our Treasurer, I would rather it were not mentioned, that as long as the Hudson's Bay Company exist this noble race must remain in status quo."15

The complete course of action that Hodgkin took during the next few months is not clear, but in December of 1836, Hodgkin wrote a lengthy letter to Treasurer Harrison. ${ }^{16}$ The subject was a new expedition proposed by Dr. King to the northern shores of North America; the object, to solicit Harrison's financial support for the venture. Hodgkin listed the advantages not only to knowledge about these little-

\footnotetext{
14 Queries respecting The Human Race, to be addressed to travellers and others. Drawn up by a Committee of the British Association for the Advancement of Science, appointed in 1839 (of which Dr. Hodgkin was Chairman). Rep. Brit. Ass. Adv. Sci. 1840, pp. 447-458.

15 Hodgkin papers, op. cit., note 13 above, 8:54. 16 Ibid., 12:69.
} 


\section{Thomas Hodgkin and Benjamin Harrison: crisis and promotion in academia}

explored regions, but also to the Medical School of Guy's Hospital, whose museum would benefit greatly from the large number of new acquisitions to be expected.

Because it is otherwise impossible to imagine the reaction of a man of Harrison's associations and temperament to what followed, and because the argument and its exposition are so characteristic of Hodgkin in their forthrightness as well as in their Quaker usage, the remainder of this lengthy letter about King is presented:

But it has been said that the Hudson's Bay Company exerts a secret opposition to his undertaking because he had made some exposures connected with their fur trade. This assertion, I hope, is not well founded: $R$. King has no hostile feelings towards the Company, nor any rival interest to serve; but on the contrary he is very sensible of the kind of assistance which his party received from the Company, and he is personally attached to many of its agents. Nevertheless as a correct observer and faithful narrator, he could neither avoid seeing, nor fail to describe the existence and operation of causes which demoralize and depopulate those vast regions which the charter of the Hudson's Bay Company has committed and subjected to their authority. The distant directors of the Hudson's Bay Company cannot see the process for themselves; their agents in the country who, in serving their interest, zealously take a part in it, are not likely to report it, and whilst they send home rich cargoes which make the prosperity of the Company, it is not very likely that the well pleased governors and shareholders will be ready to suspect, or be careful to inquire into it. It is only by the observations of an enlightened and unbiassed traveller that the truth is likely to be disclosed. When it is at length made known that a system of traffic has been long in operation, which, though less revolting in its more visible characters, is no less appalling in its ultimate results than the slave-trade itself, the Christian, the benevolent, the enlightened, and even the politic directors and members of the company must rejoice at the timely disclosure as enabling them to put a stop to the evil. A few may ridicule and despise what they may term morbid sensibility, and say that Indians are no better than wolves, and that starvation is nothing to them, when they are used to it; - the more reflecting portion must feel that, till a remedy is applied, a weight rests upon their consciences, and that even their future pecuniary advantage is in some jeopardy.

A lively interest in the fate of Aboriginal tribes which $I$ have now cherished upward of 20 years, makes me feel intensely on this subject, and will, I trust, be a sufficient apology for my having sought to arrest thy attention respecting it. Of the mass of the members and directors of the Company I know little or nothing, but I cannot believe that Benjamin Harrison, whose life is almost entirely devoted to institutions which have for their object the relief and amelioration of his fellow creatures, will either regard the subject with indifference, or have his attention fixed upon it without conceiving the means which may correct and retrieve the evil, or that he would advocate the cause in vain, were he to undertake it.

It is possible that at first under an altered system, individual cargoes, representing the life blood of the Indians, may be diminished in number and value, but eventually when the well being of the inhabitants of the wide regions over which your sway is extended, has been duly consulted, and when, instead of a few species of furs only, various resources of different kinds have been rendered productive, cargoes would be increased in number, if not in individual value, and the income, patronage and power of the Company might be extended almost indefinitely. The benefits of humane and Christian policy would be found, in interest as well as in satisfaction, abundantly to transcend those of a diametrically opposite system.

That such a happy change may be effected under thy auspices is the heartfelt desire and prayer of thy sincere and respectful friend

T. H. [Thomas Hodgkin]

The arguments seeking Harrison's support for King's expedition were replaced by a fervent plea for a change in policies of the Hudson's Bay Company. Reaction was not long in forthcoming. On 5 January 1837, Harrison informed Hodgkin in cool and uncertain terms 17 that the latter was "under a delusion" and that the statements of Richard King on which Hodgkin has based his conclusions about the Company were "falsehoods": ". . . reply to your letter . . . in terms of astonishment that you could on no higher authority than the author of his tracts have entertained an opinion of a person whose conduct in other situations in life has been under your immediate observations . . .". This vigorous protest brought from Hodgkin on 8 January 1837, 18

17 Ibid., 8:45.

18 Ibid., 12:73. 


\section{Edward H. Kass, Anne B. Carey, and Amalie M. Kass}

a shocked denial of any adverse intention. On 10 January the Treasurer summoned Hodgkin to an interview, ${ }^{19}$ when, according to Hodgkin's notes, the former pointed out his long personal and active interst in the welfare of the Indian, his financial contributions to churches for them, and his support of missions. ${ }^{20}$ Harrison attributed King's statements that the Hudson's Bay Company had not furnished instructions for the Indians to spite on account of his having been rejected for a post at Guy's, and observed that the Company had considered the previous expedition so badly contrived that orders had been given to the Company's agents "to make the researches in a much less expensive and more effectual manner."'21

Hodgkin no doubt listened politely, and he readily admitted the interest and involvement of Harrison on behalf of the natives, but he stood his ground firmly about the influence of the fur trade on the Indians. Hodgkin suggested that King may have been inadequately informed about the absence of attempts to educate the Indians, but had reported only what he saw. We do not know how this interview concluded, but whatever the immediate outcome, the disagreement between the two could not have disappeared.

In March, Hodgkin experienced what seems to have been a substantial illness: “. . . a febrile attack with protracted derangements of the alimentary canal which has considerably reduced my strength". $22 \mathrm{He}$ was sent to Lewes, Sussex, to recover. Hodgkin's peaceful convalescence in the warm surroundings of Sussex was abruptly shattered by the arrival, on 16 June, of a letter from Dr. H. M. Hughes, a colleague at Guy's, bringing news of the death of Dr. Cholmeley. ${ }^{23}$ Hughes was clearly sympathetic to Hodgkin's advancement to the position of Assistant Physician that would be vacated by Dr. Thomas Addison, who was to succeed Dr. Cholmeley as Physician. Hughes wrote that he wished to let Hodgkin know of the event as quickly as possible "that you may have an opportunity of acting as you think right with the slightest loss of time", and he offered his own services in the matter.

Hodgkin responded immediately by writing that, although he indeed intended to declare himself a candidate for the post, he thought that Hughes should also enter himself in the race, and even advised him where to seek support. ${ }^{24}$ On the same day, Hodgkin wrote also to the Treasurer 25 declaring his candidacy for the vacancy that was likely to occur, and expressing his desire, if appointed, to retain the direction of the Pathological Museum that he had done so much to create and build up.

As events unfolded, it became more and more obvious how much Hodgkin wanted his promotion. For example, during the period before the decision was made, he requested that his signature be deleted from a statement to the Reform Association

19 Ibid., $8: 48$.

20 It seems difficult to reconcile these revelations with the rumour later reported that Harrison "would have no officer of the Hospital who drove about with a North American Indian" (Wilks and Bettany, op. cit., note 2 above, p. 384). Hodgkin had arranged for several particularly bright young Indians to be brought to England for higher education and one, in particular, was a special protégé.

21 Hodgkin papers, op. cit., note 13 above, 12:73, appendage to letter. These are notes in Hodgkin's handwriting, evidently written after the interview.

22 Ibid., 8:43.

23 Ibid., 8:303.

24 Ibid., $8: 43$.

25 Ibid., 8:20. 
Thomas Hodgkin and Benjamin Harrison: crisis and promotion in academia

deploring the abuses of Dissenters by their Tory employers. ${ }^{26}$ Although he did not allude to his position, it can be inferred that he wished to do nothing to alienate Harrison and the Board of Governors, who were by and large of Tory sentiments. What is clear, in this correspondence, is Hodgkin's distress at the thought of suppressing his usual forthrightness. As time wore on, the conflict between his desire for the post and his perception of the reasons that made it unlikely that he would be promoted caused him to be less aggressive in his own behalf and led to active intervention by others who wished to further his candidacy. In particular, his brother John Hodgkin jr., a prominent lawyer, more worldly in his interests, undertook to mobilize academic support.

Shortly after Hodgkin announced his intention to seek the post, and at the urging of his supporters, he departed from Lewes for London in the company of his father. What transpired during the next several days we can only guess, but emerging opposition to his election weighed so heavily upon him that he considered withdrawing his application. He was apparently in communication with his beloved cousin Sarah Rickman during this time; a letter from her written on $4 \mathrm{July,27}$ with a brief further support from her mother, encouraged him to stand fast and to force the Treasurer to face the arguments that were being passed about against Hodgkin. At the time, these appeared to consist of his adherence to the Society of Friends, his association with the University of London, his Spitalfields lectures on medical care for the poor, 28 and his recent illness, suggesting poor health. Sarah Rickman pointed out that except for the last, all of these, to just and honourable men, would seem to have been arguments for, rather than against, his appointment, and that in fact his success would insure future good health since it would give him an even greater motive for maintaining himself in a healthy state!

Despite such encouragement, Hodgkin decided to remove himself from the arena, and to try to regain some of his strength. In the company of his cousin Henry Tuckett, he proceeded to Shipston, which was his father's home, and from there to Frenchay, the Tuckett home near Bristol, arriving on 8 July and remaining there until the end of that month. During this time he occupied himself with other considerations, including a scheme for the colonization of Cyrene Africa by the Maltese. ${ }^{29} \mathrm{He}$ had, in fact, so thoroughly removed himself from the scene that by $14 \mathrm{July}$ he was writing to his brother to say that he had had no news of Guy's since leaving London and that although he did not wish for much, he should like to have some word. 30

By this time his brother and others were becoming more active on his behalf. Hodgkin's old friend, Dr. Stroud, sensing a disappointment, advised him to withdraw his name from consideration ${ }^{31}$ for reasons of health, but John Hodgkin was not in accord with this opinion and on hearing of it from his brother, remarked that it was difficult to determine "how far [Stroud's] friendship for thee may warp his judgment

\footnotetext{
26 Ibid., 2:260.

27 Ibid., 5:20.

28 Ibid., 8:3.

29 Ibid., 6:256

30 Ibid., 7:77.

31 Ibid., 7:78.
} 


\section{Edward H. Kass, Anne B. Carey, and Amalie M. Kass}

and increase his natural timidity and caution". 32

By now Hodgkin was beginning to realize that his prolonged absence from the hospital should end, and this feeling was reinforced when he received word from Dr. Hughes that Dr. Addison considered it "most impolitic" for Hodgkin to be away for so long. 33 Not only were all the appointments (Addison's included) being deferred until Hodgkin's return, but his continued absence could only confirm the feelings that problems of health made him unfit for the appointment. Hodgkin knew that there was, in addition, a great deal of work to be done in the Museum, the arrears occasioned in part by his recent illness. He indicated that much could be accomplished in the two months remaining before the beginning of the autumn session of the medical school. While contemplating his return to the hospital, Hodgkin wrote to his brother of Harrison: "It is my sincere wish to treat him with all due respect . . . without evincing the least subserviance or asking the least favor". 34 Characteristically, Hodgkin first consulted with his father and brother before making the decision to return to London. Equally characteristically, the elder Hodgkin was not content merely to give his own advice, but sought the opinions of several others.

While consulting on the matter with John Morgan, a surgeon at Guy's and a Hodgkin ally, the father picked up a rumour that the vacant post might be divided between his son and Benjamin Babington. ${ }^{35}$ The latter was certainly a worthy candidate, son of a Physician at Guy's, brother-in-law of Richard Bright, inventor of the laryngoscope, and later one of the founders of the Epidemiological Society. ${ }^{36}$ After obtaining opinions from Drs. May (the Hodgkin family physician), Morgan, and Bright, John Hodgkin concluded that it might be reasonable for his son to proceed to London. 37

The decision having been made, Hodgkin seems to have felt no great urgency about his return, for he made plans to visit Tintern Abbey and a few other interesting places in the area, as well as to visit for a day in Bristol. 38 He left Frenchay on the last day of July 39 and proceeded to Alton, intending to arrive at Guy's on 5 or perhaps 7 August, but his progress was considerably speeded when he received from his brother the astonishing news that the Treasurer had paid the young barrister a visit on 2 August. The purpose of the interview is unclear, as are the contents, but apparently John Hodgkin jr., in his surprise, was quite forthright in his statements, perhaps too much so, by his own admission. 40 He was left with the impression that his brother could have the appointment - or half of it - but at the price of giving up the Museum. ${ }^{41}$ It was essential, John stated, for Thomas to proceed immediately to Guy's and to confer with Harrison. The tone of the letter is almost one of command, but it is easy to understand

32 Ibid., 4:182.

33 Ibid., 6:257.

34 Ibid.

35 Ibid., 4:187.

36 Fielding H. Garrison, An introduction to the history of medicine, 4th ed., Philadelphia, W. B. Saunders, 1929 , p. 742.

37 Hodgkin papers, op. cit., note 13 above, 4:187.

38 Ibid., 6:248.

39 Ibid., 7:79.

40 Ibid., 4:192.

41 Ibid., 4:188. 
Thomas Hodgkin and Benjamin Harrison: crisis and promotion in academia

how a meeting with Harrison might galvanize John Hodgkin to action.

Hodgkin speeded his travel and arrived at Guy's on the afternoon of 5 August. Harrison presented him with a plan. The proposal was that two Assistant Physicians should be appointed, but that only one of these persons should fill the customary role, which would include delivery of the clinical lectures and receipt of the resulting emolument. The nature of the other post was unclear but involved continuing curatorship of the Museum. ${ }^{42}$ Hodgkin saw the arrangement as a device for passing over him without the appearance of doing so. He wrote to his brother that he would have gone so far as to resign his place at the Museum if the assistant physicianship could become his, but a sop was clearly not to his liking, and he stated to Harrison two days later that the dual appointment was "an act in which I could not with justice to myself concur". ${ }^{43}$ Harrison's reaction, as recorded by Hodgkin, was swift and brief: "Then I shall appoint Dr. B. alone". 44 It seemed to Hodgkin that his fate was thus sealed, at least with respect to the long-desired post.

The irony was that only now did Hodgkin's brother and friends mount a major campaign on his behalf. Since the Governors were not scheduled to meet for the election until September, it is understandable that the effort should be thought worthwhile, but Hodgkin seemed to have given up. In a letter to James Browell, steward of Guy's, on 9 August, Hodgkin specifically disclaimed any connexion with or sanction of efforts that were being made to influence the Governors on his behalf, for, such efforts would be not only futile but "diametrically opposed to the object for which I am now most anxious - vis. to prove that, tho' I have failed to obtain the post which I have, for years, laboured to merit, I am sincerely endeavouring to bear the disappointment with equanimity and Christian patience".45

The following events are somewhat difficult to trace out, but what happened appears to be this: Hodgkin, perhaps feeling that his letter to Browell had not stated his position clearly enough, determined to set out his feelings to the Treasurer on paper, as precisely as possible, so that there would be no misunderstanding. He therefore drafted a letter to Harrison in which he denied firmly that he had declined the post of Assistant Physician, but had declined only the new one offered under the old name. He then resigned the curatorship of the Museum, in order to clear himself of all other obligation that might hinder him from fulfilling the duties of Assistant Physician. ${ }^{46}$ This letter he considered "as a necessary justification of myself" and "as a positive contradiction of the report by which it seems that the rulers of Guy's have attempted to shield themselves", that is, the report that he had declined the post of Assistant Physician as he understood it to be. ${ }^{77} \mathrm{He}$ left this draft with his brother and set out for Chelmsford and Ipswich, remaining at the latter place until 29 August. It seems clear that Hodgkin had no idea of actively pursuing further what he thought was a lost cause, and initially his supporters seemed to agree that his letter should not be sent. In a letter from John

\footnotetext{
42 Ibid., 8:21.

43 Ibid.

44 Ibid.

45 Ibid., 8:22.

46 Ibid., 8:47.

47 Ibid., $7: 81$.
} 
Hodgkin jr., to his brother, dated 23 August, the former expressed his feelings that "thy proposed letter must not go" and that "thy resignation of the Curatorship . . . ought not to be grounded on thy having heard of a mistaken rumour of thy having resigned the Assistant Physicianship".48 However, some as yet unknown factor must have altered the situation overnight, for on 24 August, we find that John Hodgkin jr., John Hodgkin sr., Ebenezer Smith, and John Morgan had constructed in the doctor's name another draft to the President, Treasurer, and Governors of Guy's Hospital. This letter, although containing the elements Hodgkin had originally intended to be included, was rather different in tone, being much more emphatic that his candidacy still stood. 49 This draft went to Ipswich with a note from John Hodgkin jr., urging his brother to send it to Harrison as quickly as possible.

As the election was less than two weeks away, Hodgkin's adherents now began to mobilize their efforts with great speed and activity. John Hodgkin jr., worked continually for his brother's appointment, enlisting Joseph Travers, Samuel Gurney, and other Quaker luminaries in the cause.50 Peter Bedford, James Clark, and Sir Moses Montefiore (Hodgkin was Montefiore's physician and confidante) all agreed to assist with whatever influence they might have. ${ }^{51}$ Letters were written, calls were made on various Governors by those thought likely to influence them, 52 a statement of Hodgkin's case (written by Samuel Gurney and John Hodgkin jr.) was printed and distributed.53 A committee was formed to plan overall strategy; it consisted of Ebenezer Smith, M. Hutchinson, and John Hodgkin jr. ${ }^{54}$ John Blackburn, a former student of Hodgkin's and presently a Liverpool surgeon, printed a statement, on behalf of himself and other former students, urging the Governors to appoint Hodgkin. 55 Objections to the appointment were listed and counter-replies suggested. 56 A tally of the possible vote of the Governors was evolved. ${ }^{57}$ In short, all conceivable efforts were made to secure the post for Hodgkin, and if the activity resembled frenzy and occasionally chaos, it was no less sincere.

But in the meantime, what of the doctor himself? The profound disappointment which he had sustained was still very much with him. To him, all of this effort must at first have seemed gratifying but perhaps pointless. Over the helter-skelter loomed the intransigent figure of the Treasurer, and Hodgkin knew better than most just how unyielding Harrison could be. Hodgkin wrote to his brother on 25 August that he had resigned himself to the loss and anticipated "so much that will be disagreeable should I either gain the appointment which I have asked or even continue in my old post that I could almost wish no further step to be taken at present." On the other hand, Hodgkin clearly had not completely dispelled his ambition, for he continued, "I think it however

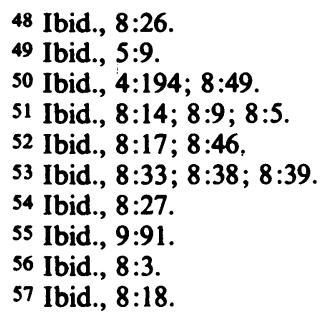




\section{Thomas Hodgkin and Benjamin Harrison: crisis and promotion in academia}

a duty to attend to the dictates of kind friends and if I do my duty I trust I shall be borne out".58 As time went on, some of his hopes were rekindled by the enthusiasm of his supporters, 59 and he briefly abandoned his rural retirement, returning to London on 29 August. Here he considered sending yet another letter to Harrison, affirming his determination to stand as a candidate and denying the rumour that he had waived the appointment. 60 This letter was not sent, Hodgkin considered ". . . that his first application is in full force, and that he had intimated his determination not to stir a finger, but to leave his case as it originally stood."

On 31 August, W. V. Arnold, Registrar of the Hospital, sent formal notice to Hodgkin that a General Court would be held on 6 September for the election of the new Assistant Physician, and that intent of candidacy should be forwarded before that date. 61 The latter was drawn up by Hodgkin in Ipswich, to which he had returned via Colchester. ${ }^{62}$ Although he was going through the motions required of him, a sense of the unlikelihood of his success had once again settled over him, and as the day of decision approached, his ambivalence became more apparent. On 2 September, he wrote to his brother that he would gladly withdraw from consideration if only his claims to qualification for the post were admitted, but to withdraw at this point might be to imply a concession of inferiority or incompetence. The injustice of his treatment rankled sorely, but at the same time he recognized what an unpleasant situation it would be if he were elected over the Treasurer's objection. ${ }^{63} \mathrm{He}$ continued, "I can truly say that I desire to do my duty, but I think it right to let you know my feelings to aid your judgment" $.64 \mathrm{He}$ felt some uneasiness at the rivalry with Babington, 65 whose father had attended Hodgkin's mother during her last years. Finally, he gave himself over to his family and friends, empowering them to act for him as their best judgment dictated. His resignation is apparent in his final lines: "Anything like flinching from want of nerve would be an ungrateful return for your kindness. I am therefore prepared to act the part which you may assign me - or to withdraw with perfect satisfaction when and how you may think fit". ${ }^{66}$

September 6 came, and the scheduled meeting took place, with the anticipated results. Harrison's will prevailed, and Babington was elected to the post by a large margin. Hodgkin was present at the session but did not write about it, so we can only imagine his emotions while his fate was being decided. He had known for a month that he was not to receive the post, but had allowed the enthusiasm of his well-intentioned supporters to raise his hopes. The opposition between his desires and his perception of almost certain failure must have only added to the pain of rejection. At last, however, all was settled, and he saw that he would be unable to bear his disappointment while

58 Ibid., 7:82.

59 Ibid., 7:83.

60 Ibid., 8:37.

61 Ibid., 8:25.

62 Ibid., 8:24.

63 Ibid., 8:50.

64 Ibid., 8:7.

65 Babington had invented a device that he called a "glottoscope". Hodgkin, meticulously trained in Latin and Greek, could not be comfortable with this hybridized word and suggested instead the word "laryngoscope", which suggestion Babington gladly accepted.

66 Hodgkin papers, op. cit., note 13 above, 8:50. 


\section{Edward H. Kass, Anne B. Carey, and Amalie M. Kass}

retaining any affiliation with the institution that, in his judgment, had nurtured and then wronged him. Before the election, he had intended to complete his work on the Museum, but, finding it impossible to continue, he resigned all his appointments on the day following the action by the Governors. ${ }^{67}$ Ignoring the urgings of Stroud 68 and Blackburn 69 that he take his case to the public, he withdrew from society, and in early October suffered a relapse of his earlier illness which effectively removed him from public activity and allowed time for the emotional wounds to begin to heal.

Subsequently, he joined the staff of St. Thomas's Hospital, and became deeply involved with dispensary practice in the clinic for the poor.

\section{ACKNOWLEDGEMENTS}

We are most grateful to Professors Thomas and Dorothy Hodgkin and to Mrs. Dorothy Hodgkin for their generous hospitality, criticisms, and many suggestions. Winfied Swanson provided thoughtful editorial comments in the preparation of this paper.

67 Ibid., 8:51.

68 Ibid., 8:10; 8:30; 8:58.

69 Ibid., 5:18. 